\title{
SWIETENIA MAHAGONI SEEDS ATTENUATE HYPERGLYCEMIA AND PROTECT LIVER IN ALLOXAN-INDUCED DIABETIC RATS
}

\author{
M. A. Hammam, G. A. Kalil, S. M. El-Sayed and I. I. Mohamed \\ Biochemistry Department, Faculty of Agriculture, Menofia University, \\ Shibin El-Kom, Egypt
}

Received: Aug. 16, 2020

Accepted: Aug. 31, 2020

\begin{abstract}
The present study was designed to investigate the chemical composition of Swietenia mahagoni seeds, identification of phenolic compounds in acetone extract in mahagoni seeds, studying the fatty acids composition, and evaluation of mahagoni extracts and oil on the glucose level of diabetes rats. The chemical composition of seeds were moisture $(3.6 \%)$, crude fiber $(14 \%)$, ash $(3 \%)$, crude protein $(13 \%)$, crude fat $(7.4 \%)$ and total carbohydrate $(62.6 \%)$. The fatty acids composition were lignoceric acid (C24) $38.23 \%$ followed by stearic acid (C18) $35.69 \%$, meanwhile the unsaturated fatty acid was linoleic acid (C18:2), which accounted for ( $26.08 \%)$. The phenolic compound in acetone extract showed that menthol and nerolidol are the major phenolic ( 12.32 and $10.06 \%$ respectively ). Ttreatment with Swietenia mahagoni seed extracts and oil decreased significantly glucose level, also decreased significantly GOT , GPT , ALP , urea , creatinine and malondialdehyde level as compared with hyperglycemic group .
\end{abstract}

Key words: Swietenia mahogany, Alloxan,hyperglycemia,diabetes.

\section{INTRODUCTION}

Swietenia mahagoni Jacq. is a small, leafy, medium sized tree found in India and some African countries, but native to West Indies. Across the world, the plant is commonly called West Indies mahogany, caoba, caob dominicana or acajou. It is one of the species of genus Swietenia which belongs to chinaberry family, Meliaceae. Elbert (1978). Fatty acid composition of $S$. mahagoni seed oil was determined as their methyl esters prepared by boron-trifluoride methanol complex , fatty acid range $C 16: 0$ to $C 20: 0$ in $S$. mahagoni seed oils containing saturated and unsaturated fatty acids. The linoleic acid enriched in fatty acid profile $\mathbf{3 0 . 1} \%$. Linoleinic acid was found to be $13.5 \%$. In the saturated fatty acids profile, stearic acid was the highest estimated as $15.8 \%$ in S. mahogany seed oils. The moisture contents of $S$. mahagoni seeds were found to be $15.2 \%$. The lipid contents were $57.9 \%$. Ash contents was estimated as $2.8 \%$ in $S$. mahagoni while total protein $(\mathrm{N} \times 6.25)$ of
S. mahagoni seeds was $13.0 \%$ of which $7.5 \%$ was water soluble. Crude fiber contents estimated as $1.4 \%$ and carbohydrate contents were determined to be $9.7 \%$. Ali et al., (2011). the potentiality of the extract of $S$. mahagoni seed for the correction of diabetes and its related complications like oxidative stress and hyperlipidemia. The extract may be a good candidate for developing a safety, tolerable, and promising neutraceutical treatment for the management of diabetes, De et al., (2011). The ethanolic extract of Swietenia mahagoni seeds has hypoglycaemic effect in experimentally induced diabetic rats which requires further investigation, Mahid-Al-Hasan et al., (2011). Aqueousmethanol extract of $S$. mahagoni seed has been reported to exhibit hypoglycemic and antihyperlipidemic potency in streptozotocin-induced diabetic rats. Oral feeding of the extract to diabetic rats for $21 \mathrm{~d}$ lowered the blood glucose level and improved liver glycogen content. Furthermore, 
treatment with the seed extract normalized the levels of serum urea, uric acid, creatinine, cholesterol, triglyceride and lipoproteins. In addition, the extract increased the activity of antioxidant enzymes and reduced the oxidative stress in liver, kidney and skeletal muscles De et al., (2011).

The aim of the present investigation was to evaluate the influence of $S$. mahagoni seed oil and seed extracts on serum lipids, liver and kidney function of hyperglycemic rats on biochemical and biological changes that may occur to diabetic rats.

\section{MATERIALS AND METHODS}

\section{Materials:}

Mahagoni seeds were collected from research center department of medical and aromatic plants. Giza Egypt. The seeds were dried and milled.

\section{Methods :}

Preparation of crude extracts from Swietenia mahagoni seeds:

Methanol, acetone and water extracts of Swietenia mahagoni. seeds were prepared by cold maceration technique.

\section{Extraction of seed oil:}

Oil extraction and degumming were carried out using the method described by Tsaknis et al. (1998). The seed oil was extracted by solvent extractions using $n$ hexane $(\mathrm{H})$.

\section{Proximate composition:}

The methods of the Association of Official Analytical Chemists AOAC, (1990) were used for proximate analysis. Mahagoni seeds samples (5 grams) was used for determination of moisture content by weighing in crucible and drying in oven at $105^{\circ} \mathrm{C}$, until a constant weight was obtained. Determination of ash content was done by ashing at $550^{\circ} \mathrm{C}$ for $3 \mathrm{~h}$. The Kjeldahl method was used to determine the protein content. The crude fibre content of the samples was determined by digestion method and the fat was done by Soxhlet extraction method. All determinations were done in triplicate. The carbohydrate content of the test sample was determined by estimation using the arithmetic difference method Pearson (1976).

$$
\begin{aligned}
& \% \mathrm{CHO}=100-(\% \text { fat. }+\% \text { ash }+\% \text { fiber }+ \\
& \% \text { protein) }
\end{aligned}
$$

\section{Identification of fatty acids:}

Saturated, unsaturated and total fatty acids were determinate in the oil by using methyl esters boron trifluoride method A.O.A.C (2012), the oil is saponified with sodium hydroxide in methanol .the fatty acids are methylised with boron tri fluoride in methanol, extracted with heptanes and determined on a gas chromatograph with FID detector (PE auto system $\mathrm{XL}$ ) with auto sampler and Ezchrom integration system . Carrier gas (He), ca.25 Psi -air $450 \mathrm{ml} / \mathrm{min}$-Hudrogen $45 \mathrm{ml}$ - split $10 \mathrm{ml} / \mathrm{min}$. oven temperature $200 \mathrm{C}$ injector and detector $250 \mathrm{C}$.

\section{Identification of Mahagoni acetone extract :}

GC / MS analysis : the analysis was carried out using a GC (Agilent Technologies 7890 A) interfaced with a mass - selective detector (MSD,Agilent 7000 ) equipped with an apolar Agilent HP-5ms ( 5\%-phenyl methyl poly siloxane )capillary column $(30 \mathrm{~m} \times 0.25 \mathrm{~mm}$ i.d. and 0.25 um film thickness ) the carrier gas was helium with the linear velocity of $\mathrm{ml} / \mathrm{min}$. The identification of components was based on compartion of their mass spectra and retention time with those of the authentic compounds and by computer matching with NIST and WILEY library as well as by compartion of the fragmentation pattern of the mass spectral data with those reported in the literature. 


\section{Biological Evaluation:}

\section{Animals:}

Adult male albino rats Sprague Dawely strain weighing between (90 100) $\mathrm{gm}$, were obtained from the animal house of Egyptian Organization for biological Products and Vaccines (VACSERA) Cairo, Egypt. The animals were kept in wire cages with wire bottom. The diet was introduced to the rats in special feed cup that kept food spilling to a minimum, water was provided to the rats by means of glass tube projecting through wire cage, an inverted bottle supported one side of the cage.

\section{Blood sampling and analysis:}

Blood samples were collected after six weeks in tubes contain heparin as an anticoagulant from the eye plexuses under diethyl ether anesthesia and then centrifuged at $3000 \mathrm{rpm}$ for $20 \mathrm{~min}$. to obtain plasma, which was kept frozen until analysis. Blood glucose was determined according to enzymatic method of Tinder, (1969). The total cholesterol was analyzed calorimetrically according to Allain et al. (1974) method . The triglycerides were analyzed according to Fossati and Prencipe (1982) method. Alanine-aminotransferase (ALT) and aspartate-aminotransferase (AST) activities were measured according to the method described by Reitman and Frankel (1957). Alkaline phosphatase
(ALP) activity was measured by the method of Hausamen et al., (1967). Urea and creatinine were determined according to Young (2001). Malondialdehyde was determined in plasma as described by Satoh, (1978). Catalase activity was determind in plasma as described by Aebi (1984)

\section{Statistical analysis:}

The results of the animal experiments were expressed as the Mean \pm SE and they were analyzed statistically using the one-way analysis of variance ANOVA followed by Duncan's test. In all cases $p<0.05$ was used as the criterion of statistical significance.

\section{RESULTS AND DISCUSSION}

\section{Proximate composition of Mahagoni seeds:}

Proximate compositions of Mahagoni seeds are presented in Table 1. Swietenia mahagoni seeds consisted of moisture (3.6\%), crude fiber (14\%), ash (3\%), crude protein $(13 \%)$, crude fat $(7.4 \%)$ and total carbohydrate (62.6\%). Our data are in line with that of Ali et al., (2011). Who reported that ash and crude protein percent of $S$. mahagoni seeds were determined. Ash contents was estimated as $2.8 \%$ while total protein $(\mathrm{N} \times 6.25)$ of $S$. mahagoni seeds was $13.0 \%$.

Table 1: Proximate composition of Moringa seeds (w/w\%)

\begin{tabular}{c|c}
\hline Constituents & Percentage (w/w \%) \\
\hline Moisture content & 3.6 \\
\hline Crude fibre content & 14 \\
\hline Total ash & 3 \\
\hline Protein content & 13 \\
\hline Crude Fat content & 7.4 \\
\hline Carbohydrate content & 62.6 \\
\hline
\end{tabular}


Fatty acids composition:

Data demonstrated in Table (2) Showed that fatty acids of Swietenia mahagoni oil contained $26.08 \%$ unsaturated fatty acids and $\mathbf{7 3 . 9 2} \%$ saturated fatty acid. the unsaturated fatty acid was linoleic acid (C18:2), which accounted for $(26.08 \%)$ of the total fatty acid. Mean while the most abundant saturated fatty acids were lignoceric acid (C24) $38.23 \%$ followed by stearic acid (C18) 35.69\%.

These data are in agreement with those obtained by Ali et al., (2011) who reported that, linoleic acid enriched in fatty acid profile $30.1 \%$ in $S$. mahagoni, may be the precursor of prostaglandins (known to occur in accessory genital gland, seminal plasma and lung tissue of human body) and play a vital role in human health .Also Harlem (2003) reported that, methyl linoleate was $(30.55 \%)$ in S. mahagoni, oil.

Chemical composition of Mahagoni acetone extract:

Phenolic compounds in acetone extract of seeds for Swietenia mahagoni were analyzed by GC/MS, and concentration of all tested phenolic compounds are given in Table ( 3 ).

From this table it was found that Swietenia mahagoni seeds contains ( 32 ) phenolic compounds. Analysis of Swietenia mahagoni acetone extract of seeds showed that menthol and nerolidol are the major phenolic (12.32 and $10.06 \%$ respectively ).

These results are compatible with those reported by Pharm et al. (2011).

Table 2: Fatty acids composition of Moringa oil:

\begin{tabular}{|c|c|c|}
\hline Fatty acids & Name & Concentration \% \\
\hline 1 & Linoleic acid & 26.08 \\
\hline 2 & Stearic acid & 35.69 \\
\hline 3 & Lignoceric acid & 38.23 \\
\hline
\end{tabular}

Table 3: Phytocomponents identified in the acetone extract of Swietenia mahagoni by GC-MS:

\begin{tabular}{|c|c|c|c|c|c|}
\hline No & Compound & $\%$ & No & Compound & $\%$ \\
\hline 1 & Dimethyl sulfoxide & 3.95 & 17 & Squalane & 1.16 \\
\hline 2 & L-(-)-Fucose & 3.58 & 18 & Cyanidin cation & 2.77 \\
\hline 3 & Resorcinol & 0.67 & 19 & Myricetin & 0.95 \\
\hline 4 & 4-Methylcatechol & 0.08 & & Ledane & 6.95 \\
\hline 5 & Phenol,2,6-dimethyl & 2.97 & 21 & 7,8 -Dihdro-a-ionone & 5.91 \\
\hline 6 & 2-Methoxy-5 methylphenol & 2.78 & 22 & Caryophyllene oxide & 5.25 \\
\hline 7 & $\begin{array}{c}2 '-H y d r o x y-4 '- \\
\text { methoxyacetophenone }\end{array}$ & 0.48 & 23 & Perillal & 1.58 \\
\hline 8 & citronellol & 2.37 & 24 & Dodecanedioic acid & 4.35 \\
\hline 9 & Eugenol & 0.53 & 25 & Kaempferol & 3.82 \\
\hline 10 & Cinnamic acid,p-hydroxy- & 0.20 & 26 & Citronellyl tiglate & 9.85 \\
\hline 11 & Phenol,3,5-di-tert-butyl- & 0.52 & 27 & Nerolidol & 10.06 \\
\hline 12 & Flopropion & 0.22 & 28 & Menthol & 12.32 \\
\hline 13 & Hexestrol & 0.24 & 29 & Apigenin 8-C-glucoside & 4.04 \\
\hline 14 & 4',7-Dimethoxyisoflavone & 0.25 & 30 & 3,5-di-t-Butylcatechol & 1.05 \\
\hline 15 & 3,5-Dimethoxycinnamic acid & 0.92 & 31 & Thunbergen & 3.69 \\
\hline 16 & Methyl tri-O-methylgallate & 0.29 & 32 & Cumaldehyde & 6.07 \\
\hline
\end{tabular}


In vivio study of the effect of Swietenia mahagoni extracts and oil on hyperglycemic rats:

Body weight, glucose level and lipids profile:

The effect of Swietenia mahagoni extracts and oil on hyperglycemic rats for 30 days on the body weight, glucose level and lipids profile of albino rats are illustrated on Table (4), which represent the mean values through the whole period. Data indicated that body weight in normal group of albino rats were $233 \mathrm{gm}$, while in hyperglycemic group body weight of albino rats were $\mathbf{1 7 2} \mathbf{g m}$ after $\mathbf{3 0}$ days, the Swietenia mahagoni extracts and oil (group III , IV , V and VI) and glibenlamide group reached 240,231 , 225,224 and $236 \mathrm{~g}$ respectively. Increased significantly body weight of albino rats treated with Swietenia mahagoni extracts and oil compared with hyperglycemic rats.

Glucose level in normal group of albino rats were $95.4 \mathrm{mg} / \mathrm{dl}$, while in hyperglycemic group glucose level of albino rats were $440.4 \mathrm{mg} / \mathrm{dl}$ after 30 days, the Swietenia mahagoni extracts and oil (group III, IV , V and VI) and glibenlamide group reached $93.6,93.2$, $134.6,104.8$ and $87.8 \mathrm{mg} / \mathrm{dl}$ respectively . reduced significantly glucose level of albino rats treated with Swietenia mahagoni extracts, oil and glibenlamide compared with hyperglycemic rats.

Plasma total cholesterol in normal group of albino rats were $160 \mathrm{mg} / \mathrm{dl}$, while in hyperglycemic group total cholesterol level of albino rats reached $148.4 \mathrm{mg} / \mathrm{dl}$ after 30 days, the Swietenia mahagoni extracts and oil ( group III , IV , $\mathrm{V}$ and $\mathrm{VI}$ ) and glibenlamide group reached $149.2,148.8,164,155.8$ and $160.6 \mathrm{mg} / \mathrm{dl}$ respectively, plasma triglycerides in normal group of albino rats were $133.6 \mathrm{mg} / \mathrm{dl}$, while in hyperglycemic group triglycerides level of albino rats reached $106 \mathrm{mg} / \mathrm{dl}$ after 30 days, the Swietenia mahagoni extracts and oil (group III , IV , V and VI) and glibenlamide group reached 145.6, 142.6 , $129,126.8$ and $136.8 \mathrm{mg} / \mathrm{dl}$ respectively .

Our data are in line with that of De et al., (2011), Maiti et al., (2009) and Kalaivanan \& Pugalendi (2011).

Table 4: Effect of Swietenia mahagoni extracts and oil on body weight glucose level and lipids profile of rats :

\begin{tabular}{c|c|c|c|c}
\hline Group & Weight (gm) & $\begin{array}{c}\text { Glucose } \\
(\mathrm{mg} / \mathrm{dl})\end{array}$ & $\begin{array}{c}\text { cholesterol } \\
(\mathrm{mg} / \mathrm{dl})\end{array}$ & $\begin{array}{c}\text { Triglycerides } \\
(\mathrm{mg} / \mathrm{dl})\end{array}$ \\
\hline Negative control group & $233^{\mathrm{a}} \pm 1.48$ & $95.4^{\mathrm{ab}} \pm 5.45$ & $160^{\mathrm{ab}} \pm 1.16$ & $133.6^{\mathrm{ab}} \pm 3.51$ \\
\hline Positive control group & $172^{\mathrm{b}} \pm 0.58$ & $440.4^{\mathrm{d}} \pm 3.6$ & $148.4^{\mathrm{a}} \pm 1.88$ & $106^{\mathrm{a}} \pm 5.26$ \\
\hline Methanol extract group & $240^{\mathrm{a}} \pm 2.58$ & $93.6^{\mathrm{a}} \pm 5.17$ & $149.2^{\mathrm{a}} \pm 4.81$ & $145.6^{\mathrm{b}} \pm 5.27$ \\
\hline Acetone extract group & $231^{\mathrm{a}} \pm 2.14$ & $93.2^{\mathrm{a}} \pm 1.92$ & $148.8^{\mathrm{a}} \pm 4.14$ & $142.6^{\mathrm{b}} \pm 1.95$ \\
\hline Water extract group & $225^{\mathrm{a}} \pm 1.58$ & $134.6^{\mathrm{c}} \pm 3.84$ & $164^{\mathrm{b}} \pm 3.11$ & $129^{\mathrm{ab}} \pm 8.84$ \\
\hline Oil group & $224^{\mathrm{a}} \pm 1.98$ & $104.8^{\mathrm{b}} \pm 3.56$ & $155.8^{\mathrm{ab}} \pm 2.38$ & $126.8^{\mathrm{ab}} \pm 2.16$ \\
\hline Glibenlamide group & $236^{\mathrm{a}} \pm 2.16$ & $87.8^{\mathrm{a}} \pm 2.86$ & $160.6^{\mathrm{ab}} \pm 1.92$ & $136.8^{\mathrm{b}} \pm 5.45$ \\
\hline
\end{tabular}


Liver functions GOT, GPT and ALP activity:

The effect of Swietenia mahagoni extracts and oil on hyperglycemic rats for 30 days on GOT, GPT and ALP activity of albino rats are illustrated on Table (5), which represent the mean values through the whole period. Data indicated that Glutamate oxaloacetate transferase (GOT) activity in normal group of albino rats were $22.6 \mathrm{IU} / \mathrm{L}$, while in hyperglycemic group GOT activity of albino rats reached $25.8 \mathrm{IU} / \mathrm{L}$ after 30 days, the Swietenia mahagoni extracts and oil (group III, IV , V and VI) and glibenlamide group reached $23.2,24.2$, $24.2,24$ and $28.2 \mathrm{IU} / \mathrm{L}$ respectively. Glutamate pyrovate transferase (GPT) activity in normal group of albino rats were $20.4 \mathrm{IU} / \mathrm{L}$, while in hyperglycemic group GPT activity of albino rats reached 32.8 IU/L after 30 days, the Swietenia mahagoni extracts and oil ( group III , IV ,
$\mathrm{V}$ and $\mathrm{VI}$ ) and glibenlamide group recorded $19.6,20,20.8,21.2$ and 23.6 IU/L respectively .

Alkaline phosphatase (ALP) activity in normal group of albino rats were 125 IU/L, while in hyperglycemic group ALP activity of albino rats reached $148.6 \mathrm{IU} / \mathrm{L}$ after 30 days, the Swietenia mahagoni extracts and oil ( group III , IV , V and VI) and glibenlamide group recorded 114 , $120,128.8, \quad 121.8$ and $134.4 \mathrm{IU} / \mathrm{L}$ respectively. Reduced significantly GOT, GPT and ALP activity of albino rats treated with Swietenia mahagoni extracts, oil and glibenlamide group compared with hyperglycemic rats.

Our data are in line with that of Subhadip Hajra et al., (2011) and Siva Prasad Panda et al., (2010), who reported that, using of $S$. mahagoni Jacq. seeds as a natural antioxidant and antidiabetic agent.

Table (5): Effect of Swietenia mahagoni extracts and oil on GOT , GPT and ALP activity of rats :

\begin{tabular}{c|c|c|c}
\hline Group & GOT (IU/L) & GPT (IU/L) & ALP (IU/L) \\
\hline Negative control group & $22.6^{\mathrm{a}} \pm 0.54$ & $20.4^{\mathrm{a}} \pm 0.55$ & $125^{\mathrm{bc}} \pm 2.73$ \\
\hline Positive control group & $25.8^{\mathrm{c}} \pm 1.09$ & $32.8^{\mathrm{c}} \pm 2.86$ & $148.6^{\mathrm{e}} \pm 1.22$ \\
\hline Methanol extract group & $23.2^{\mathrm{ab}} \pm 1.3$ & $19.6^{\mathrm{a}} \pm 0.55$ & $114^{\mathrm{a}} \pm 1.58$ \\
\hline Acetone extract group & $24.2^{\mathrm{b}} \pm 0.83$ & $20^{\mathrm{a}} \pm 1$ & $120^{\mathrm{ab}} \pm 1.58$ \\
\hline Water extract group & $24.2^{\mathrm{b}} \pm 1.09$ & $20.8^{\mathrm{a}} \pm 0.83$ & $128.8^{\mathrm{cd}} \pm 1.48$ \\
\hline Oil group & $24^{\mathrm{b}} \pm 1.22$ & $21.2^{\mathrm{a}} \pm 1.92$ & $121.8^{\mathrm{b}} \pm 1.64$ \\
\hline Glibenlamide group & $28.2^{\mathrm{d}} \pm 0.83$ & $23.6^{\mathrm{b}} \pm 1.14$ & $134.4^{\mathrm{d}} \pm 1.67$ \\
\hline
\end{tabular}




\section{Kidney functions:}

\section{Plasma creatinine and plasma urea:}

Results are given in Table (6) represented the mean values through the whole period. Data indicated that plasma urea in normal group of albino rats were $18 \mathrm{mg} / \mathrm{dl}$, while in hyperglycemic group urea level of albino rats reached 35.6 $\mathrm{mg} / \mathrm{dl}$ after 30 days, the Swietenia mahagoni extracts and oil ( group III , IV , $\mathrm{V}$ and $\mathrm{VI}$ ) and glibenlamide group recorded $20.4,22.6,20.6,23$ and 24.8 $\mathrm{mg} / \mathrm{dl}$ respectively, plasma creatinine in normal group of albino rats were 0.902 $\mathrm{mg} / \mathrm{dl}$, while in hyperglycemic group urea level of albino reached $1.136 \mathrm{mg} / \mathrm{dl}$ after 30 days, the Swietenia mahagoni extracts and oil ( group III , IV , V and VI) and glibenlamide group $0.946,0.93$, $0.938,0.956$ and $0.986 \quad \mathrm{mg} / \mathrm{dl}$ respectively. Reduced significantly urea and creatinine levels of albino rats treated with Swietenia mahagoni extracts, oil and glibenlamide group compared with hyperglycemic rats. Our data are in line with that of $\mathrm{De}$ et al., (2011) , who studied The antidiabetic, antioxidative, and antihyperlipidemic activities of aqueous-methanolic extract of Swietenia mahagoni seed in streptozotocin-induced diabetic rats and reported that, the seed extract corrected the levels of serum urea and creatinine level towards the control level in this experimental diabetic model.

\section{Oxidative stress parameters :}

Malondialdehyde (MDA) and Catalase (CAT) activity:

Results are given in Table (7) indicated that plasma malondialdehyde in normal group of albino rats were 14.58 $\mathrm{mg} / \mathrm{dl}$, while in hyperglycemic group malondialdehyde level of albino rats were $16.87 \mathrm{mg} / \mathrm{dl}$.The Swietenia mahagoni extracts and oil ( group III , IV , V and VI) and glibenlamide group recorded 15.45 , $16.22,15.78,15.79$ and $14.86 \mathrm{mg} / \mathrm{dl}$ respectively . Catalase (CAT) activity in normal group of albino rats were 509 IU/L, while in hyperglycemic group CAT activity of albino rats were $539.2 \mathrm{IU} / \mathrm{L}$, the Swietenia mahagoni extracts and oil (group III , IV , V and VI) and glibenlamide group recorded 527, 507.6 , 503, 522 and $526.2 \mathrm{IU} / \mathrm{L}$ respectively.

Table (6): Effect of Swietenia mahagoni extracts and oil on urea and creatinine levels of rats

\begin{tabular}{c|c|c}
\hline Group & Urea (mg/dl) & Creatinine (mg/dl) \\
\hline Negative control group & $18^{\mathrm{a}} \pm 1$ & $0.902^{\mathrm{a}} \pm 0.019$ \\
\hline Positive control group & $35.6^{\mathrm{d}} \pm 2.3$ & $1.136^{\mathrm{d}} \pm 0.061$ \\
\hline Methanol extract group & $20.4^{\mathrm{ab}} \pm 1.8$ & $0.946^{\mathrm{abc}} \pm 0.05$ \\
\hline Acetone extract group & $22.6^{\mathrm{bc}} \pm 1.14$ & $0.93^{\mathrm{ab}} \pm 0.015$ \\
\hline Water extract group & $20.6^{\mathrm{ab}} \pm 4.4$ & $0.938^{\mathrm{abc}} \pm 0.03$ \\
\hline Oil group & $23^{\mathrm{bc}} \pm 1.58$ & $0.956^{\mathrm{bc}} \pm 0.02$ \\
\hline Glibenlamide group & $24.8^{\mathrm{c}} \pm 1.3$ & $0.986^{\mathrm{c}} \pm 0.034$ \\
\hline
\end{tabular}


M. A. Hammam, et al.,

Table (7): Effect of Swietenia mahagoni extracts and oil on MDA level and CAT activity of rats

\begin{tabular}{c|c|c}
\hline Group & MDA (mg/dl) & Catalase (IU/L) \\
\hline Negative control group & $14.58^{\mathrm{a}} \pm 0.835$ & $509^{\mathrm{a}} \pm 3.13$ \\
\hline Positive control group & $16.87^{\mathrm{b}} \pm 0.947$ & $539.2^{\mathrm{a}} \pm 4.98$ \\
\hline Methanol extract group & $15.45^{\mathrm{ab}} \pm 1.3$ & $527^{\mathrm{a}} \pm 5.68$ \\
\hline Acetone extract group & $16.22^{\mathrm{ab}} \pm 1.58$ & $507.6^{\mathrm{a}} \pm 2.38$ \\
\hline Water extract group & $15.78^{\mathrm{ab}} \pm 1.55$ & $503^{\mathrm{a}} \pm 1.76$ \\
\hline Oil group & $15.79^{\mathrm{ab}} \pm 1.3$ & $522^{\mathrm{a}} \pm 3.2$ \\
\hline Glibenlamide group & $14.86^{\mathrm{ab}} \pm 1.58$ & $526.2^{\mathrm{a}} \pm 1.58$ \\
\hline
\end{tabular}

\section{REFERENCES}

Aebi H. (1984). Catalase, In vitro. Methods in Enzymology, 105: 121-126.

Ali, M.A. Sayeed, M.S. Islam, M.S. Yeasmin, G.R.M.A.M. Khan and Ida I. Muhamad (2011). Physicochemical and antimicrobial properties of trichosanthes anguina and swietenia mahagoni seeds. Bull. Chem. Soc. Ethiop. 2011, 25(3), 427-436.

Allain, C.C., L.S. Poon, C.S.G. Chan, W. Richmond and P.C. Fu (1974). Clin Chem, 20: 470.

A.O.A.C. (1990). 15th Official methods of Analysis. Association Official Analysis Chemists, Washington D.C. USA. Pp. 807-928.

A.O.A.C. (2012). Official methods of analysis of the Association of Official Analytical Chemists . International No. 994. 12. chapter 4,P.9-13.19 ${ }^{\text {th }}$ Edition.

De, D., K. Chatterjee, K.M. Ali, T.K. Bera and D. Ghosh (2011). Antidiabetic potentiality of the aqueous-methanolic extract of seed of Swietenia mahagoni (L.) Jacq. in streptozotocin-induced diabetic male albino rat: a correlative and evidence-based approach with antioxidative and antihyperlipidemic activities. Evid Based Complement Alternat Med. 2011; 2011: 892807.

Elbert, L. (1978). Atlas of United States trees. Washington, D.C.: U.S. Dept. of Agriculture, Forest Service. 3-5.

Fossati, F. and L. Prencipe (1982). Plasma triglycerides determined calorimetrically with an enzyme that produces hydrogen peroxide. J.Clin.Chem, 28(10) : 2077-2080.

Harlem Marpaung (2003). The analysis of fatty acids components in the seeds of swietenia mahogany jaco, Jurnal Sains Kimia , 7(1): 26-27.

Hausamen, T. V., R. Helger, W. Rick and W. Gross (1967). Optimal conditions for the determination of serum alkaline phosphatase by a new kinetic method. Clin. Chem. Acta., 15: 241 245.

Kalaivanan, K. and K.V. Pugalendi (2011). Antihyperglycemic effect of the alcoholic seed extract of Swietenia macrophylla on streptozotocindiabetic rats. Pharmacognosy research, 3(1): pp.67-71. 
Mahid-Al-Hasan, S., M. Khan and B. Umar (2011). Effect of Ethanolic Extract of Swietenia mahagoni Seeds on Experimentally Induced Diabetes Mellitus in Rats. Faridpur Medical College Journal, 6(2), pp.70-73.

Maiti, A. (2009). Evaluation of antidiabetic activity of the seeds of Swietenia macrophylla in diabetic rats. Available at:

http://informahealthcare.com/doi/abs/10.1 080/13880200802436703\#.VHgV_fvulB c.mendeley [Accessed November 28, 2014].

Pharm, A.J. (2011). REVIEW. , 1(1), pp.14.

Pearson, D.A. (1976). The Chemical analysis of foods, 7th ed. (Edinburgh: Churchill Livingstone,.

Retiman, S. and S. Frankel (1957). Colorimetric determination of GOT and GPT. Am.J.Clin.Path. 28:56.

Satoh, K (1978). Clinica Chimica Acta, 9037

Siva Prasad Panda, Pallab Kanti Haldar, Samit Bera, Soumitra Adhikary,
Chandi Charan Kandar. (2010). Antidiabetic and antioxidant activity of Swietenia mahagoni in streptozotocininduced diabetic rats. Pharm Biol; 48 (9): 974- 979.

Subhadip Hajra, Archana Mehta, Pinkee Pandey and Suresh Prasad Vyas. (2011 May). Antioxidant and AntiDiabetic Potential of ethanolic extract of Swietenia mahagoni (Linn.) seeds, IJPRD; Vol 3/Issue 4/Article 25: 180186

Tinder, P. (1969). Determination of glucose in blood using glucose oxidase with alternative oxygen acceptor. Annals Clinical Biochemistry 22(2):158-61.

Tsaknis, J., S. Lalas, V. Gergis, V. Dourtoglou and V. Spiliotis (1998). A total characterization of Moringa oleifera Malawi seed oil. La Rivista Italiana sostanza Grasse, 75: 21-27.

Young, DS (2001). Effects of disease on clinical lab.tests. 4th ed AACC American Association for Clinical Chemistry . 
بذور الماهوجنى تعالج الفئران المصابة بمرض السكر باستخدام الالوكزان مع حماية الكبد

مصطفى عبدالله همام ، جابر عبدالوهاب خليل ، صلاح منصور السيد ، إبراهيم إبراهيم محمد البراء قسم الكيمياء الحيوية الزراعية - كلية الززاعة - جامعة المنوفية

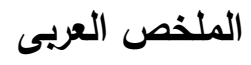

تهاف هذة الدراسة إلى دراسة التركيب الكيميائى لبذور الماهوجنى - تركيب الأحماض الدهنية الداخلة فى تركيب

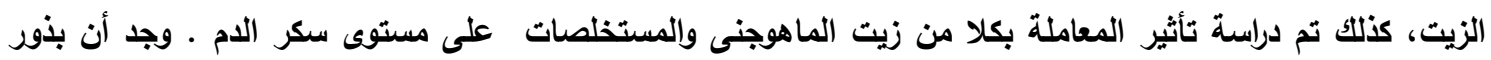

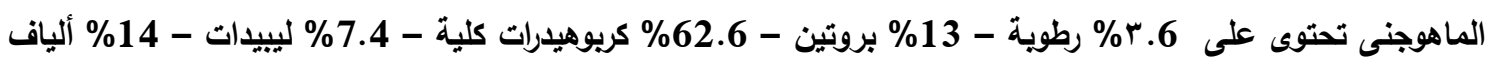

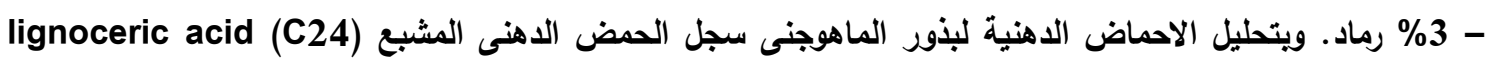
نسبة 38.23 \% فى حين سجل حمض (C18) نسبة 35.69 \% م بينما الحمض الدهنى الغير مشبع linoleic acid (C18:2) menthol و هerolidol هى المركبات الاساسية بالمستخلص بنسب 12.32 و 10.06 \% على الترتيب 12.32 )

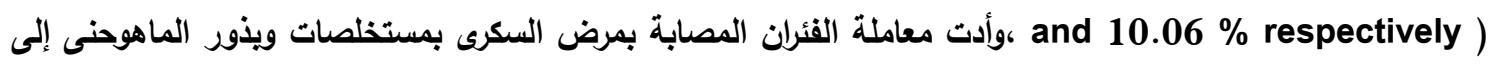
خفض معنوى فى مستوى سكر الدم كذلك المعاملة أدت إلى خفض معنوى فى نثاط إنزيمات

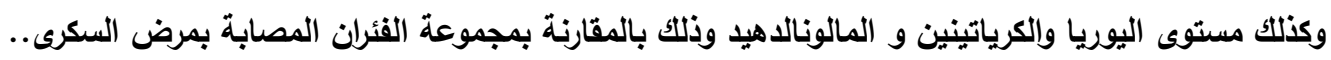


$\underline{\text { Swietenia mahagoni seeds attenuate hyperglycemia and protect liver ............ }}$ 